\title{
Introduction to part III
}

\author{
Kai K. Kimppa \\ Secretary, IFIP WG 9.2 and SIG 9.2.2 \\ Lecturer, Information Systems, Department of Information Technology \\ University of Turku - Finland \\ kakimppa@utu.fi
}

The governance of the information society is one of the major issues of today in the field of ICT and is especially important in the economic and social fields. How to govern the technology, how to govern content-or whether either should be governed-are questions to which there seem to be as many answers as there are participants in the discussion. The stakeholders in the governance issue are multifold. At the topmost level we need to have international bodies directing the development of governance, such as the initiative by the United Nations (WSIS). But both at the international and national levels the various approaches taken by governments to the development of the information societies they are creating must also be taken directly into account. As Berleur has repeatedly pointed out (2003; Berleur and Poullet, 2006), a good and fair governance of the Internet is crucial for the formation of the information society. It cannot be left to the hands of one nation only (i.e. the United States) but should - in the interests of an ethical and socially responsible approach - take account of the international combination of interests involved. Even with the best of intentions, it is not possible for one nation to take all parties into account.

Of course citizens need to have some say, via various means, on the creation of the information societies in which they are stakeholders. The new social contracts need to be, at least in part, socially constructed through the participation of the citizens of these information societies. However, to be able to do this citizens' need to be informed.

Academia also has an interest in creating governance in the information society. This happens by the academic researches through explaining the nature of how the information society develops, but also in cooperation with the commercial functioners and various levels of government activity in RTD projects such as the EU FP projects. Again, a socially responsible and ethically sound approach should be more than just window dressing in these projects.

Finally, we cannot and should not forget the economic and commercial push towards evermore advancing ICTs. The choices made in the commercial organisations as well as the market pressures they experience form our information

Please use the following fornat when citing this chapter:

Kimppa, K.K., 2007, in IFIP International Federation for Information Processing, Volume 233, The Information Society: Innovations. Legitimacy, Ethies and Democracy, eds. P. Goujon, Lavelle, S., Duquenoy, P., Kimppa, K., Laurent, V., (Boston: Springer), pp. $75-76$. 
society; the information society in which we, as participants, whether willing or pushed into it by the tidal wave of development must live in. Short term requirements of shareholder value gain cannot be the only requirement for the information society's development, instead a consistent policy relating to governments, people and international organisations should be found.

A new social contract for the new society, the information society, must be created. It cannot be a stagnant social contract, but one that takes the stakeholders as well as the rapidly changing environment in which they function into account. In the following chapters, the main stakeholders and their interests are looked into. At least these stakeholders should be a vivid part of the negotiations for the new contractwe cannot let any of them fall through gaps in the process.

\section{References}

Berleur, J. (2004) Ethics and the Requlations of the Internet, in P. Duquenoy, S. Fischer Hübner, J. Holvast and A. Zuccato (eds.) Risks and Challenges of the Network Society, Karlstad University Press, pp. 1 1 -9.

Berleur, J. and Poullet, Y. (2006) What Governance and Regulations for the Internet? Ethical Issues, in Zielinski, C., Duquenoy, P. and Kimppa, K. (eds.) The Information Society, Emerging Landscapes, IFIP Springer Series in Computer Science, Springer, pp. 169-191. 